\title{
Development of River Rating Curves for Simple to Complex Hydraulic Structure Based on Calibrated HEC-RAS Hydraulic Model, in Kwale, Coastal Kenya
}

\author{
Calvince Wara $^{1 *}$, Mike Thomas ${ }^{1}$, Suleiman Mwakurya ${ }^{1}$, Jacob Katuva ${ }^{2}$ \\ ${ }^{1}$ Rural Focus Ltd., Nairobi, Kenya \\ ${ }^{2}$ University of Oxford, Oxford, UK \\ Email: ^waracalvince@gmail.com
}

How to cite this paper: Wara, C., Thomas, M., Mwakurya, S. and Katuva, J. (2019) Development of River Rating Curves for Simple to Complex Hydraulic Structure Based on Calibrated HEC-RAS Hydraulic Model, in Kwale, Coastal Kenya. Journal of Water Resource and Protection, 11, 468-490. https://doi.org/10.4236/jwarp.2019.114028

Received: January 10, 2019

Accepted: April 27, 2019

Published: April 30, 2019

Copyright $\odot 2019$ by author(s) and Scientific Research Publishing Inc. This work is licensed under the Creative Commons Attribution International License (CC BY 4.0).

http://creativecommons.org/licenses/by/4.0/

\begin{abstract}
Accurate and reliable river flow information is critical to planning and management for sustainable water resources utilization. Most of engineering activities related to hydrologic designs, flood, drought, reservoirs and their operations are heavily dependent on the river flow information derived from river rating curve. The rating curve for a given river section is normally developed from a set of direct stage-discharge measurements for different periods. This involves considerable labour, risk and resources, and presupposes a complex and extensive measuring survey. Extrapolating the rating curve beyond the measured range, as common in many cases, is fraught with errors and uncertainties, due to the complex hydraulic behaviour of the surface water profile in transition from section, channel, downstream and flood plain controls which are often poorly understood with direct measurements. Hydraulic modeling has recently emerged as one of the more promising methods to efficiently develop accurate rating curves for a river section with simple or complex hydraulic structures and conditions. This paper explores the use of a Hydraulic Engineering Center-River Analysis System (HEC-RAS) model to review and develop river rating curves for three hydrometric stations on two rivers in Kwale, coastal Kenya. The HEC-RAS models were set up based on topographical (cross section and longitudinal) survey data for the reaches and engineering drawings for the hydraulic structures commonly used as section controls for flow measurement. The model was calibrated under unsteady state conditions against measured stage-discharge data which were captured using a Velocity Current Meter (Valeport) and an Acoustic Doppler Current Profiler (ADCP) for both low and high flow. The rating curves were extracted from model results and the uncertainty associated with
\end{abstract}


each rating curve analyzed. The results obtained by the HEC-RAS model were satisfactory and deemed acceptable for predicting discharge across the stage range at each river section.

\section{Keywords}

River Rating Curve Development, Hydraulic Simulation of Stage-Discharge Relationship, HEC-RAS Model Calibration

\section{Introduction}

River flow information is a critical requirement for surface water resources assessment, planning and management [1]. Engineering designs and hydrological studies for water supply development projects rely heavily on the accuracy of the river flow information obtained from rating curves [2]. The rating curve describes the relationship between water level (stage) and discharge (flow) at a specific cross section in a river channel [3] [4] and is used to generate a continuous discharge record from the times series of recorded river stage [5] [6].

Conversely, most hydrologic models provide outputs expressed as discharge and the rating curve is used to convert these to stage [7] [8]. Rating curves remain the primary tool for converting water level into discharge or associating stage with sediment yield [9] [10]. The curves are established using direct water stage and velocity measurements at a discrete location during different flow conditions (particularly including high flow conditions) [11] [12]. The use of simple hydraulic formulae such as Manning's equation to define the stage-discharge relationship is another method often used [13] [14].

Unfortunately, under unsteady river flow conditions, the two approaches do not guarantee accurate estimation of the discharge [15], due to the underlying steady state assumptions and the extrapolation of the rating curve beyond the range of actual measurements used to derive it [16] [17]. Furthermore, the extrapolation of the rating curve beyond the observed stage range based low and medium flow conditions are fraught with errors [18] and unquantifiable uncertainties due to modified flow dynamics of a river reach's sectional constrictions [19]. In addition, the direct measurement of river discharge at different stages and time involves a great deal of labour, resources, risk and presupposes a complex and extensive measuring survey that must be repeated frequently to keep the rating curve updated [20]. Finally, the rating curve may vary over time due to seasonal changes in vegetation, human activities and flooding [19] [21] [22].

So, the development and maintenance of a rating curve can be time consuming and fraught with uncertainty [23]; significant advances have been made in hydraulic modeling, showing the potential to reduce the time and effort required to develop reliable and accurate rating curves for any open channel section with simple to complex hydraulic structures [3] [15]. Variations in water level with 
discharge in open channels are more easily understood within 1- or 2-dimensional hydraulic modeling environments [24] [25]. This is because discharge and stage are river variables dependent upon the complex interaction of channel characteristics and flow conditions.

The use of hydraulic models to generate and improve river flow information has recently gained considerable traction worldwide. However, few models have looked at the common hydraulic structures (control sections) such as bridge and weir sections commonly used for water level monitoring in Sub-Saharn Africa. Lam [3] used a hydraulic model to develop a river rating curve based on remote sensing and Light Detection and Ranging (LiDAR) data. Mansanarez used a Stage-Fall-Discharge (SFD) model and Bayesian approach to develop river rating curves and associated uncertainty for the Madeira River in the Amazon basin. Ward and Thomas [12] used HEC-RAS hydraulic models to develop and review rating curves for the Pilbara, Kimberley, Harding, Moochalabra and Ophthalmia Dams in Western Australia. They discussed the impacts of underestimated rating curves on the design of hydraulic infrastructures. Their study recommended that rating curves developed through direct stage-discharge measurement should be checked using hydraulic flow models for reliability.

Di Baldassarre, Castellarin and Brath [26] undertook a comprehensive hydraulic analysis on the River Po (Northern Italy) with five calibrated HEC-RAS models developed using topographical ground survey data and flood hydrographs. The study confirmed that significant uncertainty exists with statistical stage-discharge extrapolation, instead recommending the use of hydraulic modeling to derive stage-discharge rating curves in situations with significant uncertainties. The study also suggested that the indirect measurement of discharge beyond the measurement range should rely on a physically-based model rather than the traditional approach of extrapolating rating curves based on analytical relationships. Di Baldassarre, et al., [26] and Castellarin et al., [27] illustrated the accuracy and reliability of the HEC-RAS model to accurately reproduce the hydraulic behavior of the Rivers Po (Italy) and Severn (UK). Sönmez and Doğan [28] and Mansanarez et al., [29] built, calibrated and validated 1D and 2D HEC-RAS and DHI MIKE 11 models to simulate flood inundation areas in the Cedar River basin (Iowa, USA). Doherty [30] calibrated a HEC-RAS model for rating curve development in semi-arid Western Australia.

Lee et al., [31] and Shao et al., [32], showed that uncertainty in rating curves can be significantly reduced using calibrated hydraulic models to simulate water surface profiles, especially with the complex hydraulic structures commonly used as section controls.

\section{Study Objectives}

The main objectives of the study were:

1) To review the existing rating curve for the Mukurmudzi River at 3KD06 gauging station.

2) To develop reliable river rating curves for the newly installed monitoring 
stations at:

a) The KISCOL weir on the Mukurumudzi River;

b) The Eshu Bridge on the Ramisi River.

\section{Study Area and River Reaches}

The study area is located in Kwale County, within the coastal part of Kenya. The area experiences a sub-humid climate with mean annual precipitation ranges from $900 \mathrm{~mm}$ to $1400 \mathrm{~mm}$ and mean temperature ranges between $20^{\circ} \mathrm{C}$ to $32^{\circ} \mathrm{C}$. The rivers experience high flows during both long (March-May) and short (October-December) rain seasons, while low river flow is experience during dry period of January-February and July-September. The study examined two rivers at 3 different locations and reaches in the area (Figure 1 and Table 1).

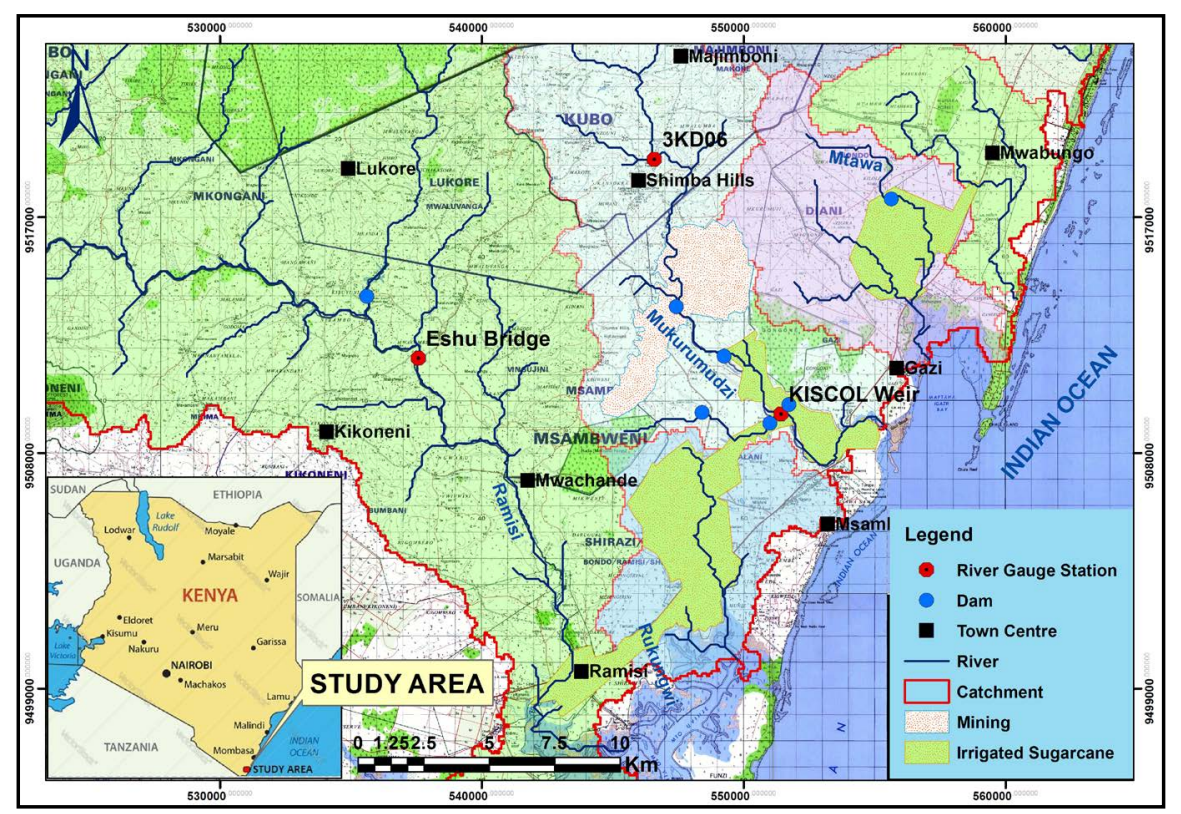

Figure 1. The study area location and river gauge stations.

Table 1. River station characteristics.

\begin{tabular}{cccccc}
\hline River Name & Catchment Area $\left(\mathbf{k m}^{2}\right)$ & Station Name & $\begin{array}{c}\text { Grid Reference } \\
\text { (Datum Arc 1960) }\end{array}$ & \% of the Catchment Area & Hydraulic Structure \\
\hline Mukurumudzi & 205 & 3KD06 & $546,595,9,519,210$ & 44 & Rectangular Weir \\
Mukurumudzi & 205 & KISCOL Weir & $551,431,9,509,485$ & 81 & Diversion Weir-Sluice \\
Ramisi & 1430 & Eshu Bridge & $537,581,9,511,612$ & 89 & Bridge \\
\hline
\end{tabular}

\subsection{Mukurumudzi River}

The Mukurmudzi River flows from the Shimba Hills National Reserve and drains into the Indian Ocean. It is an important source of water for major commercial activities in the area; mining (Base Titanium Ltd., or Base) and irrigated agriculture (Kwale International Sugar Company, KISCOL). The river is also the main source of domestic water for the Shimba Hills Settlement Scheme and 
supports the mangrove ecosystem in the estuary in the Indian Ocean near Gazi Bay. However, despite the critical economic and environmental importance of this river, the assessment and quantification of this water resource is constrained by the accuracy and confidence in the rating equation for the monitoring station [33] [34] [35]. Therefore, two different sites on the Mukurmudzi River were studied:

\section{1) Shimba Hills at $3 \mathrm{KD} 06$}

This site is the most upstream station on the river and is ideal for natural flow monitoring. The station was established in the 1950s by the Hydraulics Branch of the Kenya Public Works Department. The station consists of $1.55 \mathrm{~m}$ by $0.6 \mathrm{~m}$ rectangular weir section (Figure 2), located $12 \mathrm{~m}$ upstream of a road bridge. The station is currently instrumented with both a staff gauge and an automatic water level logger.

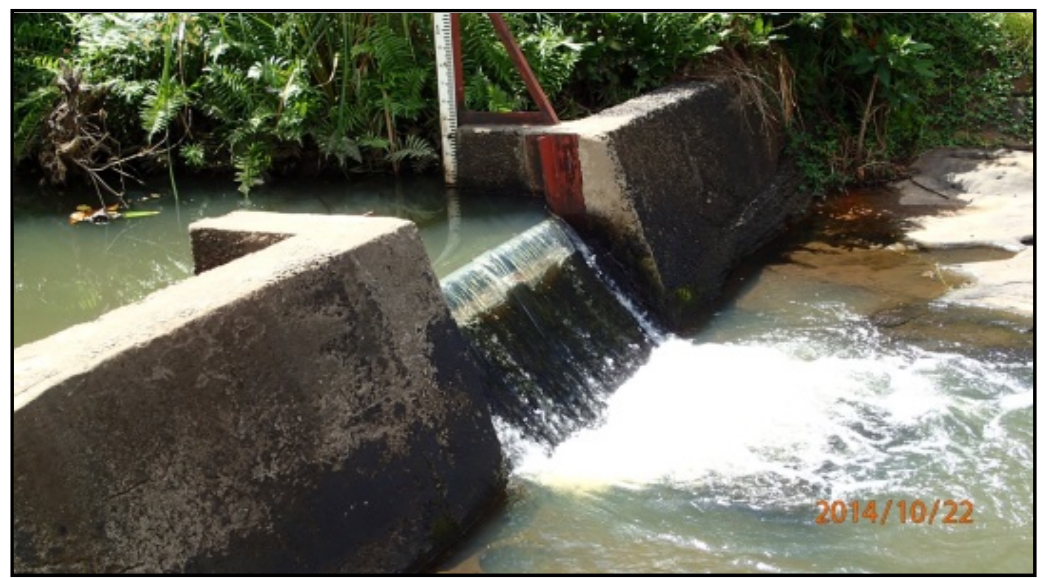

Figure 2. Mukurmudzi river 3KD06 weir section.

The weir was rehabilitated by the Water Resources Authority (WRA) with support from Base Titanium in March 2013. The rating curve was established on the basis of direct stage-discharge measurements conducted in 1967, 1970, 1980 and 1990. In 2011, Tiomin (the precursor to Base Titanium Ltd) contracted Streamtec of Australia to undertake a hydrological study on the river based on Manning's equation, which gave rise to the Streamtec 2011 rating equation [36]. In 2014, after the weir repair, Base contracted Rural Focus Ltd. to undertake a topographical survey and analyse the rating curve at $3 \mathrm{KD} 06$. There was an unexplained discrepancy between the 2011 Streamtec rating curve and that developed by RFL in 2014 [37], which were developed using the same flow parameters [35]; this discrepancy provides a basis for the review of flow conditions in the HEC-RAS model environment.

The road bridge located immediately downstream of $3 \mathrm{KD} 06(12 \mathrm{~m})$ has three piers which constrain high flows, which then switches flow control from the weir to the bridge section. The river reach was topographically surveyed $150 \mathrm{~m}$ upstream and downstream of the weir, and these data and the as-built 
weir drawings were used to define structure geometries in the HEC-RAS model.

\section{2) KISCOL Weir}

This site is located in the lower non-tidal reach downstream of the Base and KISCOL Mukurmudzi Dams. It was selected by Gro for GooD (https://upgro.org/consortium/gro-for-good/) and the WRA to monitor residual flow. It consists of a diversion weir works with a welded sluice gate ( $1 \mathrm{~m}$ by $0.7 \mathrm{~m}$ ), opening with the zero mark elevation at $11.60 \mathrm{~m}$ above mean sea level (a msl). The site was instrumented with both a manual staff gauge and an automatic water level logger installed in 2016 under the Gro for GooD Project (Figure 3).

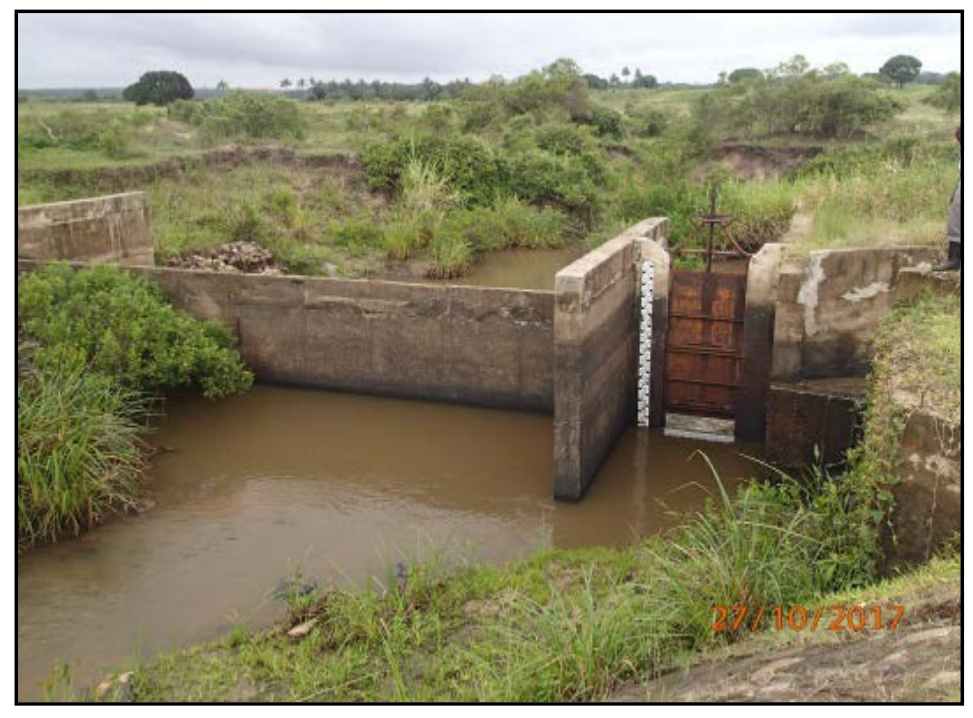

Figure 3. Kiscol weir diversion works.

A river reach section of $60 \mathrm{~m}$ was surveyed $(30 \mathrm{~m}$ upstream and downstream of the weir). The station is free of tidal influence and ideal for monitoring compliance with environmental flow conditions.

\subsection{Ramisi River}

The Ramisi River rises from small, ephemeral tributaries in the Chenze Ranges and flows to the Indian Ocean at Ramisi where it supports a mangrove ecosystem near Funzi Island. The river is saline and highly mineralized due to the inflow of brackish geothermal waters from the Mwananyamala hot springs; it is unsuitable for both domestic and agricultural uses [38] [39]. The downstream reaches are tidal and not suitable for river flow monitoring.

A river flow monitoring site was established at the Eshu Bridge on the C108 road, instrumented with both a manual gauge and an automatic water level logger on the right bank abutment (Figure 4). The site is ideal for high flow gauging due to the stable control section (although crocodiles are known to migrate along the river at high flows making high flow gauging a risky task). The river reach section was surveyed $60 \mathrm{~m}$ upstream and downstream of the bridge and the data used to build the HEC-RAS model. 


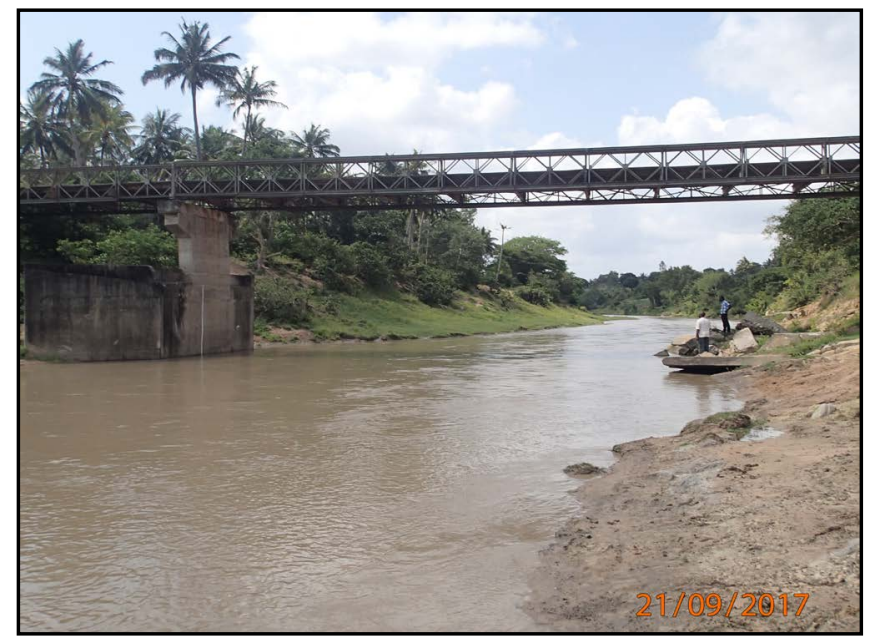

Figure 4. Ramisi River, Eshu bridge section.

\section{Description of HEC-RAS Model and Data}

The hydraulic modeling software, Hydraulic Engineering Center-River Analysis System (HEC-RAS 5.03) is a widely used open source hydraulic flow analysis programme developed by the United States Army Corps of Engineers-Hydrologic Engineering Center [40] [41]. It has been widely applied for the hydraulic modeling of open channel systems to simulate water surface profiles for flood studies [21] [28], dam break analysis [42], sediment transport [8], hydraulic structures such as culverts, bridges and weirs [43], and flood protection dykes [31]. The model is available for $1 \mathrm{D}$ and $2 \mathrm{D}$ modeling. Although the $2 \mathrm{D}$ model accurately models complex topography, it is not computationally efficient and is less suitable for modeling in-channel structures compared to the 1D model [28]. Therefore in this study a 1D HEC-RAS model was developed and calibrated against observed stage-discharge data for the three sites. The ID model is based on a finite difference solution of the full Saint-Venant equations of mass and momentum conservation. The model solves the equations using a four-point implicit box finite difference scheme developed for channels [41]. The scheme is non-dissipative and stable in a semi-implicit form (weighting factor of 0.6) under unsteady flow conditions. The model is capable of handling the flow transitions of sub-critical and super-critical conditions. A mixed flow regime can also be employed within the model. The model can be configured for different hydraulic structures such as culverts, bridges, gated spillways, overflow weirs, weirs (sluice or radial, broad, ogee or sharp crested), and drop structures [43].

\section{Materials and Methodology}

The most important input data for HEC-RAS Model 5.03 are topographical data defining river channel and flood plain geometry, engineering drawings for the various hydraulic structures and Manning's $\mathrm{n}$ values for channel and floodplain roughness. Measured stage-discharge data were used to calibrate and validate the model. 


\subsection{Geometric Data}

To develop a 1D hydraulic model, the definition of model geometry with adequately well-spaced cross sections for the study reach is required. This ensures overall accuracy and model stability [27] [44]. In this study river reach geometric data were obtained through topographical field surveys using Promark 3 RTK equipment [45] during the low flow period of February 2017. This involved selecting $x, y$ and $z$ points, both longitudinally and across the river section, with a $30 \%$ overlap into the flood plain. The survey extended upstream and downstream of the control section where the water level monitoring equipment was installed (Figure 5 and Figure 6).

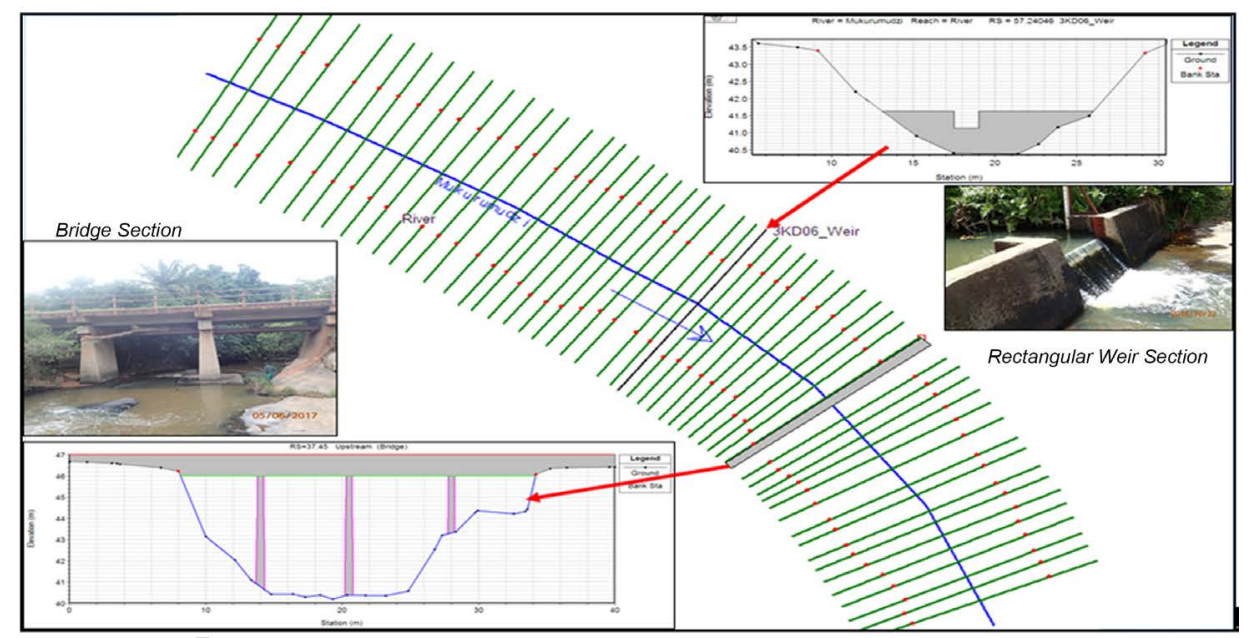

Figure 5. HEC-RAS Geometry of Mukurumudzi River for 3KD06 weir and bridge reach.

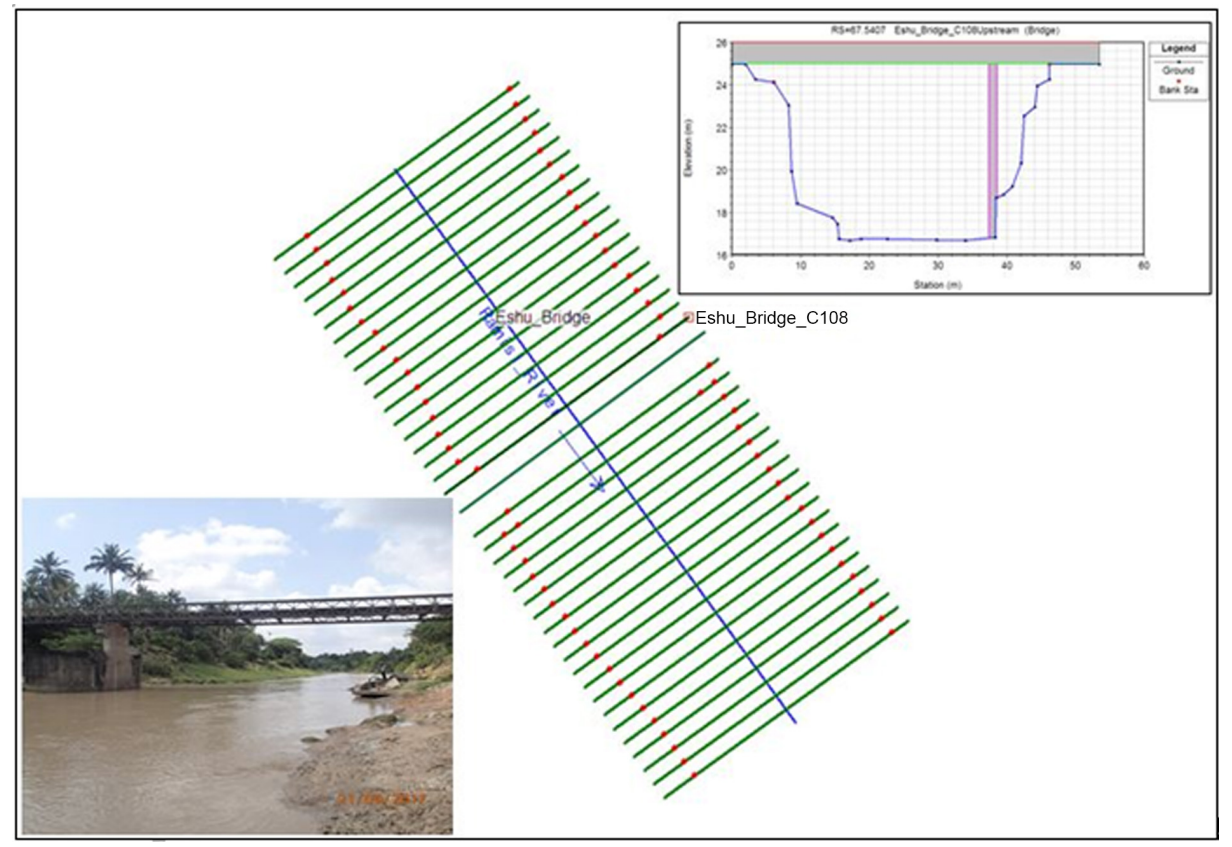

Figure 6. Geometry of the Ramisi River in the Eshu Bridge reach in HEC-RAS with bridge section. 


\subsection{Manning's n Values for River Channel and Flood Plains}

Initially, Manning's n values for each river reach and structure were determined by comparing photographs of the river reaches and flood plains with Chow [46] which presents Manning's $\mathrm{n}$ values for channels and floodplains. Figure 7 shows a typical river section for the Mukurumudzi River upstream of the weir at 3KD06, with channel and flood plain Manning's $\mathrm{n}$ values of 0.035 and 0.07 respectively.

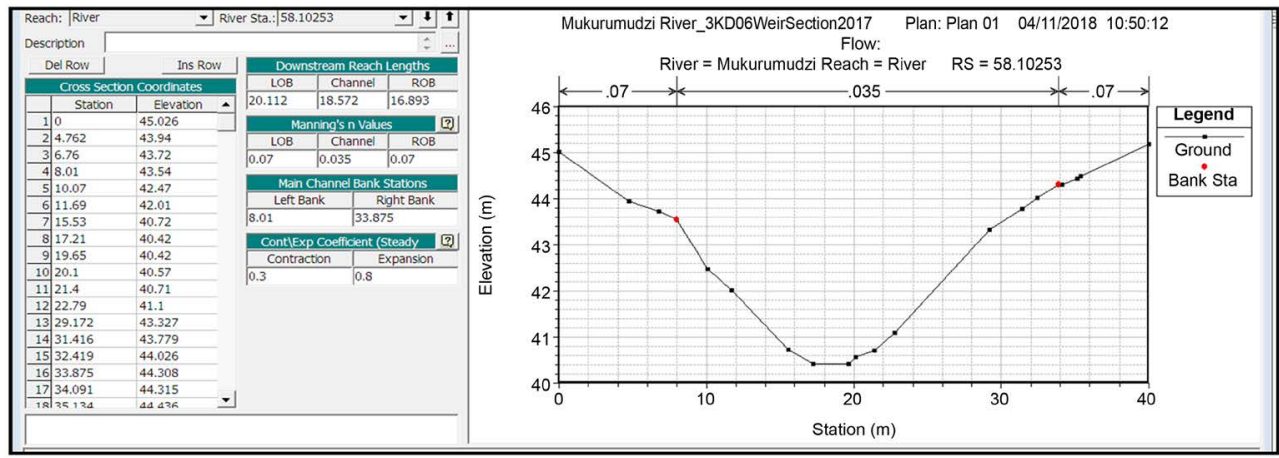

Figure 7. Manning's n values for channel and flood plain cross section at 3KD06.

\subsection{Model Boundary and Initial Conditions}

The model boundary conditions were defined as synthetic storm hydrographs at the upstream end of the river section reach (the first cross section) and the friction slope at the downstream end of the model [40] [41] [47]. Initial conditions were based on carefully selected initial flow values (extreme minimum flow). The synthetic storm hydrographs were designed to represent the entire possible flow range at the watershed outlet (the monitoring location) [48] [49]. The effects of travel time and channel or floodplain storage within the reaches were also taken into account. Two synthetic storm hydropaths were developed (Figure 8) for (a) the Ramisi-Eshu Bridge and Mukurumudzi River at 3KD06 and (b) Mukurumudzi River KISCOL diversion weir. The design hydrographs were routed through the channel reaches using the HEC-RAS models.

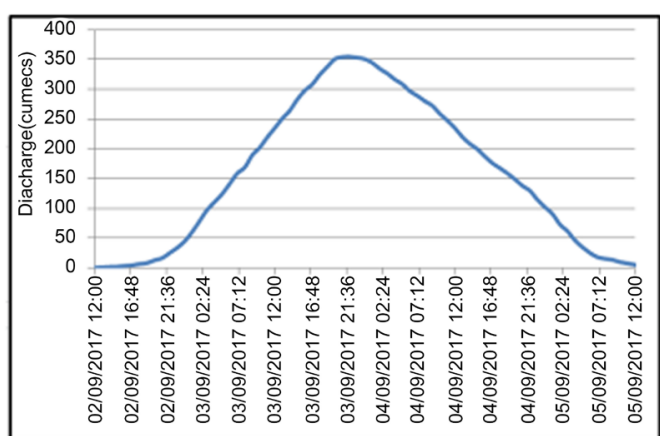

(a)

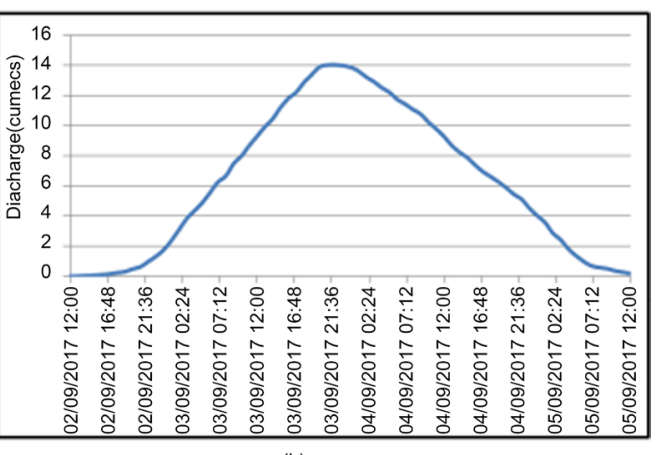

(b)

Figure 8. Synthetic hydrographs. (a) Ramisi-Eshu Bridge and Mukurumudzi-3KD06; (b) Mukurumudzi-KISCOL. 


\subsection{Stage-Discharge Measurement Campaigns}

Stage-discharge data for calibration and validation of the HEC-RAS models for the three hydrometric stations were obtained through hydrological measurement campaigns carried out using both an Acoustic Doppler Current Profiler (ADCP) and a Valeport current meter for low and medium flow periods in 2014, 2017 and 2018 at the three water level monitoring sites. The campaigns were undertaken with support from the Water Resources Authority (WRA) of Kenya (Figure 9).

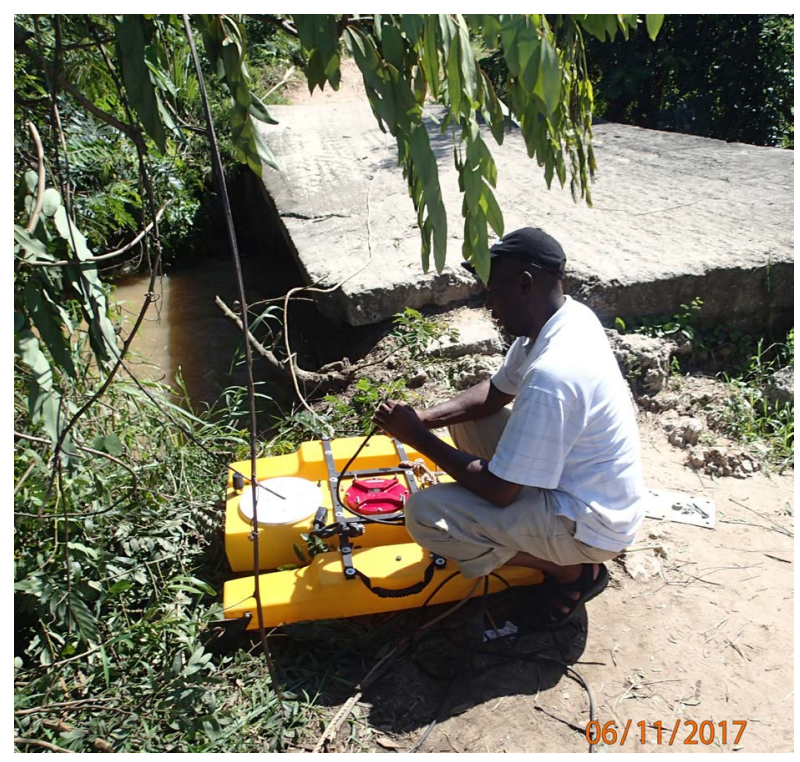

Figure 9. WRA Officer deploying ADCP equipment downstream of the KISCOL weir.

During high flow events, the bridge located $12 \mathrm{~m}$ downstream of the 3KD06 weir on the Mukurumudzi River is overtopped (Figure 10), implying that the flow through the station is controlled by the bridge which acts as a pressurized

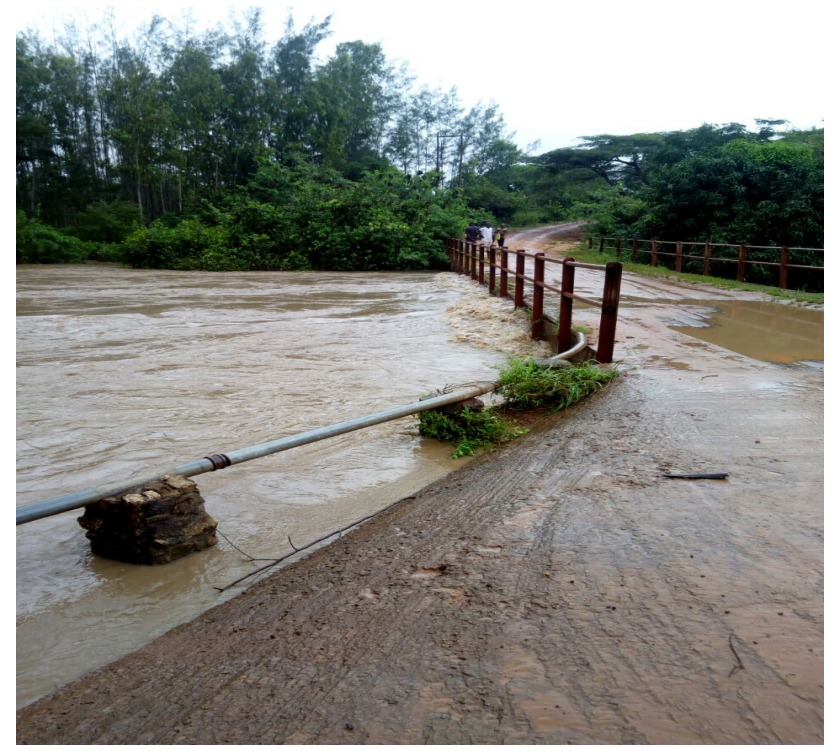

Figure 10. The Mukurumudzi River overtops the bridge at 3KD06. 
conduit (i.e. a culvert) and overtopping weir. This condition will certainly affect the rating curve and illustrates the uncertainties inherent in extending the low flow rating curve to high flow conditions.

\subsection{Model Calibration and Sensitivity Analysis}

It is always important for the model to be calibrated with observed values to establish Manning's $n$ values and weir coefficients [30] [40]. The HEC-RAS models were calibrated against the measured stage-discharge data by adjusting Manning's $\mathrm{n}$ and weir coefficient values until an acceptable correlation was established with measured stage-discharge data for both low and medium flows. Roughness coefficients and time steps (Courant Number Criteria) as well as initial flow values in the system were used to ensure that model stability was achieved during unsteady flow simulations [35].

\section{Results and Discussions}

\subsection{Mukurumudzi River 3KD06 Station-Rating Curve Review}

The topographical surface for 3KD06 with the weir and bridge as incorporated in the HEC-RAS Model is presented in Figure 11. This shows the simulated water surface profile for an inflow discharge of $0.53 \mathrm{~m}^{3} / \mathrm{s}$ at a stage of $0.43 \mathrm{~m}(41.57 \mathrm{~m} \cdot \mathrm{asl})$.

In the absence of significant looping, or hysteresis, every stage value must correspond to the same discharge during both the rising and falling limbs of the storm hydrograph [16]. The Mukurumudzi River 3KD06 model was stable, with insignificant hysteresis (Figure 12). The highest peak flow occurred at the same time as the highest stage. For the range of flows within the synthetic storm hydrograph, the backwater effect on the river model result was insignificant.

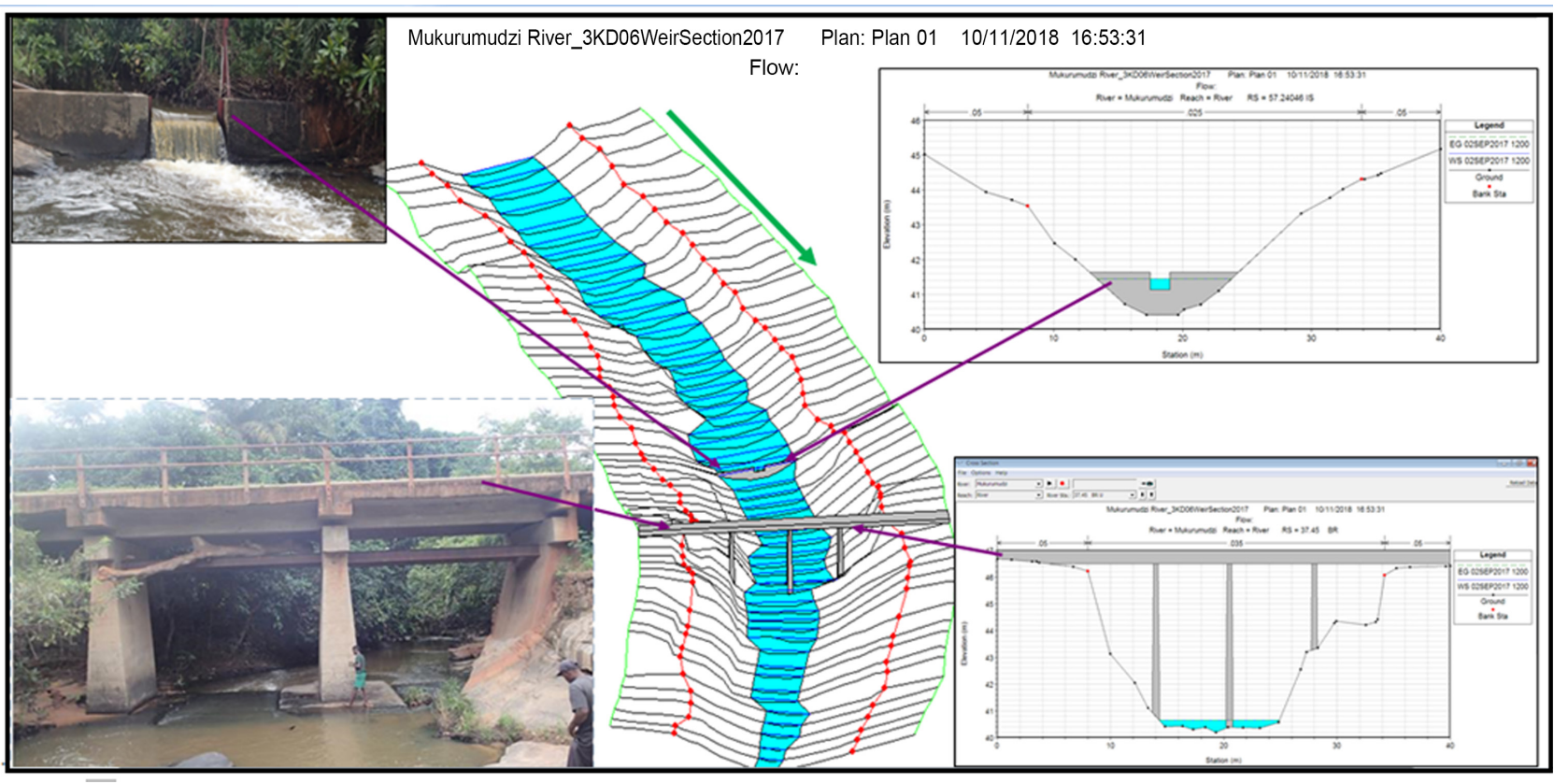

Figure 11. HEC-RAS simulated topographical surface profile of the weir and bridge at a flow of $0.53 \mathrm{~m}^{3} / \mathrm{s}$ at $0.43 \mathrm{~m}$. 


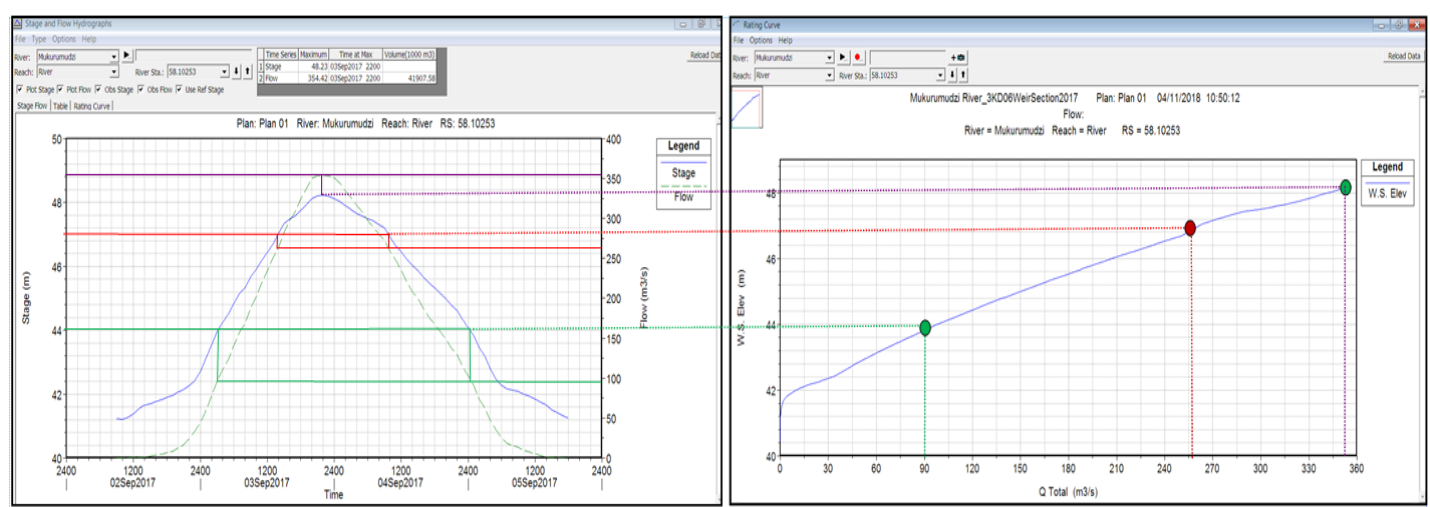

Figure 12. Simulated storm hydrograph and rating curve for the cross section upstream of the 3KD06 weir.

During calibration, the best fit with the observed data was obtained with Manning's $\mathrm{n}$ values of 0.05 (right bank flood plain), 0.04 (main channel) and 0.07 (left bank flood plain) as can be seen in Figure 13. The staff gauge's zero mark at $41.14 \mathrm{~m}$ and the simulated surface water at $42.33 \mathrm{~m}$ elevation (stage 1.2 $\mathrm{m})$, the flow of $23.6 \mathrm{~m}^{3} / \mathrm{s}$, was simulated against the observed flow of $21.9 \mathrm{~m}^{3} / \mathrm{s}$ (Figure 14). However, given the impracticality of measuring flows above $1.5 \mathrm{~m}$, the calibrated model was taken to hold for high flows at the river section and
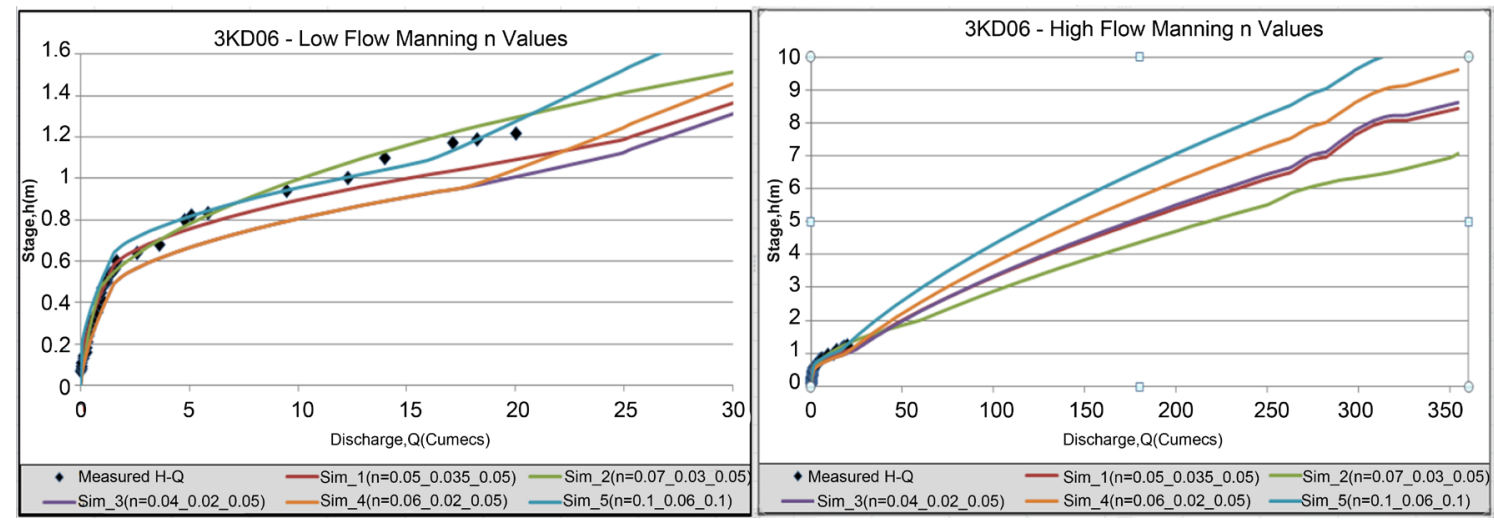

Figure 13. Simulated flow at $1.2 \mathrm{~m}$ stage at $3 \mathrm{KD} 06$.

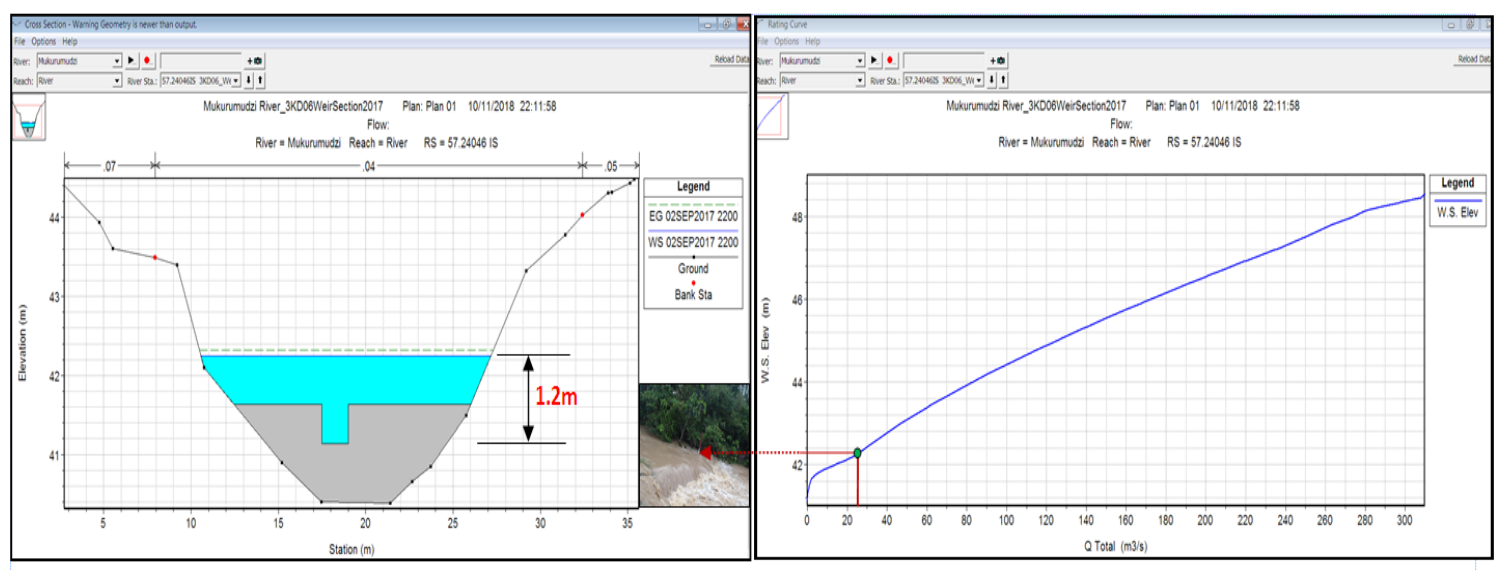

Figure 14. Simulated flow at $1.2 \mathrm{~m}$ stage (water surface elevation of $42.34 \mathrm{~m}$ ) at 3KD06. 
flood plain. The extracted rating curve values from the calibrated and simulated HEC-RAS model were then best fitted with multi-segment rating equations. This rating curve was compared graphically and statistically with the previous rating curves developed by the Ministry of Water and Irrigation (MWI) for the period 1967-1995 (Table 2), and the 2011 Streamtec and 2014 Rural Focus rating curves [37] (Table 3) as shown in Figure 15 and Figure 16.

Table 2. Approved Rating Equation for 3KD06 by the Ministry of Water and Irrigation $\left(\mathrm{MWI}, \mathrm{Q}=\mathrm{A}(\mathrm{H}-\mathrm{DH})^{\mathrm{B}}\right)$.

\begin{tabular}{ccccccccc}
\hline ID & SDATE & EDATE & SEG & LWL & HWL & A_CONST B_CONST & DH \\
\hline 3KD06 & $22 / 04 / 1967$ & $23 / 06 / 1978$ & 1 & 0.0 & 0.50 & 3.301 & 1.5064 & 0 \\
3KD06 & $22 / 04 / 1967$ & $23 / 06 / 1978$ & 2 & 0.5 & 1.82 & 10.18 & 3.1412 & 0 \\
3KD06 & $24 / 06 / 1978$ & $02 / 09 / 1980$ & 1 & 0.0 & 0.32 & 7.422 & 2.2157 & 0 \\
3KD06 & $24 / 06 / 1978$ & $02 / 09 / 1980$ & 2 & 0.32 & 0.5 & 3.301 & 1.5064 & 0 \\
3KD06 & $24 / 06 / 1978$ & $02 / 09 / 1980$ & 3 & 0.5 & 1.82 & 10.18 & 3.1412 & 0 \\
3KD06 & $03 / 09 / 1980$ & $31 / 12 / 1995$ & 1 & 0.0 & 0.50 & 3.301 & 1.5064 & 0 \\
3KD06 & $03 / 09 / 1980$ & $31 / 12 / 1995$ & 2 & 0.5 & 1.82 & 10.18 & 3.1412 & 0 \\
\hline
\end{tabular}

Table 3. 3KD06 stream multi-segment stage-discharge relationship; Streamtec, RFL and HEC-RAS.

\begin{tabular}{|c|c|c|c|}
\hline Study & Method Used & Depth Range (m) & Fitted Rating Equation \\
\hline \multirow{3}{*}{ Streamtec 2011} & \multirow{3}{*}{$\begin{array}{c}\text { Manning Equation \& H-Q } \\
\text { measurement }\end{array}$} & $0.0<\mathrm{h}<0.0 .12$ & $\mathrm{Q}=1.752 \mathrm{~h}-0.007$ \\
\hline & & $0.12<\mathrm{h}<1.0$ & $Q=9.67 h^{2}+0.03$ \\
\hline & & $1.0<\mathrm{h}<8.5$ & $\mathrm{Q}=2.9066 \mathrm{~h}^{2}+10.313 \mathrm{~h}-2.417$ \\
\hline \multirow{2}{*}{ RFL 2014} & \multirow{2}{*}{$\begin{array}{l}\text { Extrapolation based on the } \\
\text { H-Q measurement }\end{array}$} & $0<\mathrm{h} \leq 0.55$ & $\mathrm{Q}=3.77 \mathrm{~h}^{1.643}$ \\
\hline & & $\mathrm{h}>0.55$ & $\mathrm{Q}=11.64 \mathrm{~h}^{3.464}$ \\
\hline \multirow{3}{*}{ HEC-RAS } & \multirow{3}{*}{$\begin{array}{c}\text { 1D hydraulic modeling } \\
\text { calibrated with measured } \\
\text { H-Q }\end{array}$} & $0<\mathrm{h} \leq 0.5$ & $Q=3.2778 h^{2}+1.1065 h-0.0071$ \\
\hline & & $0.5<\mathrm{h} \leq 1.2$ & $\mathrm{Q}=12.677 \mathrm{~h}^{3.5375}$ \\
\hline & & $\mathrm{h}>1.2$ & $\mathrm{Q}=20.458 \mathrm{~h}^{1.4395}$ \\
\hline
\end{tabular}

Figure 15 shows graphical comparisons of the four rating curves at 3KD06 for both low flow and high flow. For the low flow range $\left(<1.0 \mathrm{~m}^{3} / \mathrm{s}\right)$, the HEC-RAS model, and the RFL 2014 and MWI (1967-1995) equations acceptably reproduced observed flows while the Streamtec 2011 equation underestimated $(\mathrm{h}<0.8 \mathrm{~m})$ and overestimated $(\mathrm{h}>1.0 \mathrm{~m})$ observed flows. However, significant uncertainty still exists for stage values above $1.2 \mathrm{~m}$, with all four rating curves showing various discharge values for a given stage value. The MWI (1967-1995) and RFL 2014 equations appear unrealistic, with exceedingly high flows for stage values above $1.5 \mathrm{~m}$. For example, the two rating curves suggest unrealistic flows of $2280 \mathrm{~m}^{3} / \mathrm{s}$ and $4547 \mathrm{~m}^{3} / \mathrm{s}$ respectively for a gauge height of $5.6 \mathrm{~m}$, the level at which the bridge overtops (Figure 10). The MWI rating equations were only valid for stage values less than $1.82 \mathrm{~m}$ (Table 2); 
therefore extrapolation above $1.82 \mathrm{~m}$ is unreliable (as shown in Figure 15 and Table 4; and Figure 16).
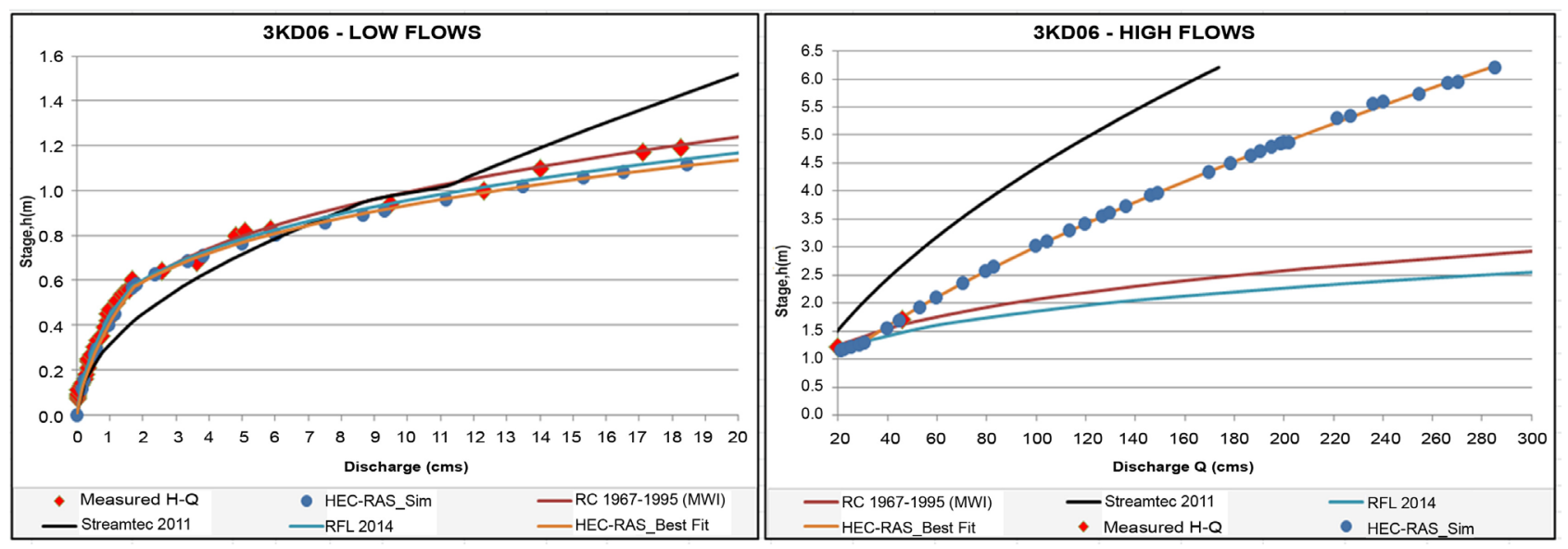

Figure 15. Comparison of 3KD06 low and high flows for the four rating curves.

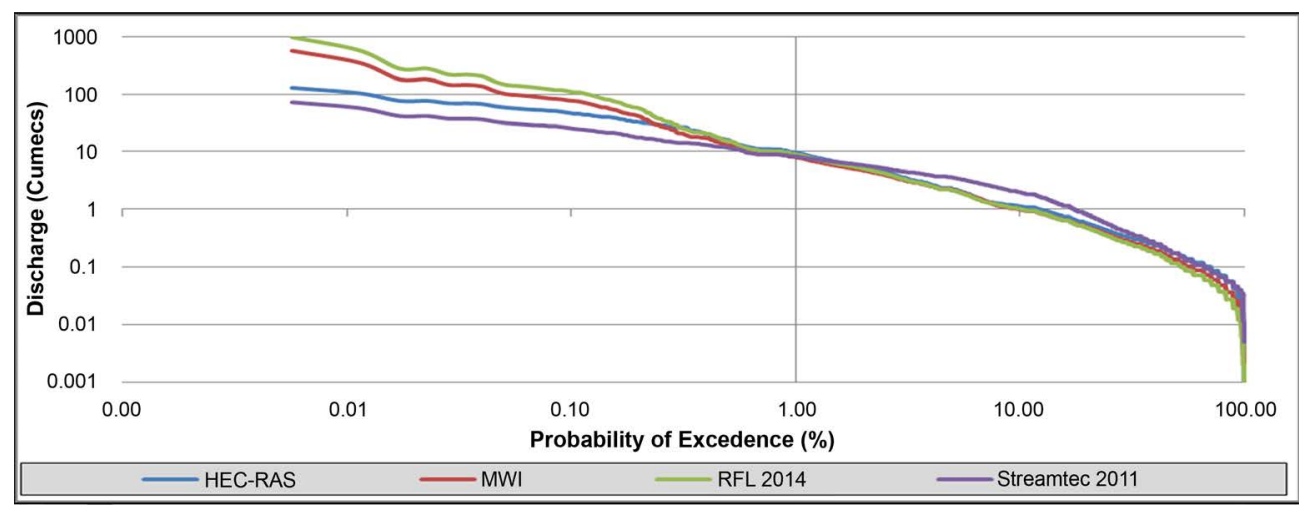

Figure 16. Flow Frequency Curves at 3KD06 for the four rating equations.

Table 4. Mukurumudzi River flow frequency for each of the four rating curves.

\begin{tabular}{|c|c|c|c|c|c|c|c|}
\hline \multirow[b]{2}{*}{ Frequency } & \multirow{2}{*}{$\begin{array}{c}\text { HEC-RAS } \\
\mathrm{m}^{3} / \mathrm{s}\end{array}$} & \multicolumn{2}{|c|}{ MWI } & \multicolumn{2}{|c|}{ RFL 2014} & \multicolumn{2}{|c|}{ Streamtec 2011} \\
\hline & & $\mathrm{m}^{3} / \mathrm{s}$ & $\begin{array}{c}\% \text { of } \\
\text { HEC-RAS }\end{array}$ & $\mathrm{m}^{3} / \mathrm{s}$ & $\begin{array}{c}\% \text { of } \\
\text { HEC-RAS }\end{array}$ & $\mathrm{m}^{3} / \mathrm{s}$ & $\begin{array}{c}\% \text { of } \\
\text { HEC-RAS }\end{array}$ \\
\hline $\mathrm{Q}_{99}$ & 0.004 & 0.003 & 75 & 0.002 & 50 & 0.011 & 275 \\
\hline $\mathrm{Q}_{95}$ & 0.029 & 0.017 & 59 & 0.012 & 41 & 0.04 & 138 \\
\hline $\mathrm{Q}_{80}$ & 0.071 & 0.048 & 68 & 0.037 & 52 & 0.066 & 93 \\
\hline $\mathrm{Q}_{50}$ & 0.173 & 0.135 & 78 & 0.116 & 67 & 0.17 & 98 \\
\hline $\mathrm{Q}_{10}$ & 1.114 & 0.991 & 89 & 1.015 & 91 & 1.989 & 179 \\
\hline $\mathrm{Q}_{1}$ & 9.608 & 7.969 & 83 & 9.053 & 94 & 8.216 & 86 \\
\hline $\begin{array}{l}\text { Maximum Flow }(\text { Maximum } \\
\text { recorded stage }=3.6 \mathrm{~m} \text { ) }\end{array}$ & 129.318 & 569.121 & 440 & 983.976 & 761 & 72.394 & 56 \\
\hline $\begin{array}{c}\text { Mean Flow } \\
(\text { stage }=0.18 \mathrm{~m})\end{array}$ & 0.585 & 0.595 & 102 & 0.69 & 118 & 0.663 & 113 \\
\hline $\begin{array}{l}\text { Minimum Flow (Minimum } \\
\text { recorded stage }=0.05 \mathrm{~m} \text { ) }\end{array}$ & 0.001 & 0.002 & 200 & 0.001 & 100 & 0.002 & 200 \\
\hline
\end{tabular}


Incorrect or erroneous rating curves can result in significant over or under-estimation of water resource availability, which can affect water allocation decisions. It may also lead to misconceptions in the design of water resources infrastructure. Flow frequency analysis based on discharge derived using the four rating equations and the 3KD06 observed water level data for 1960 to 2018 (Figure 16 and Table 4) indicates that the Streamtec 2011 ratings overestimate (more than 100\%) environmental flow $\left(Q_{95}\right)$ and mean flow. The Streamtec rating also underestimates very high flows $\left(Q_{1}-Q_{5}\right)$, so the use of such a rating curve would have significant impacts on water allocation plans. Furthermore, the MWI and RFL 2014 ratings significantly overestimate annual maximum and high flows (Table 4).

A higher level of model residual or uncertainty, based on parameter fitting, was experienced at transition (downstream through the section and flood plain controlled), and high flows as shown through the regression analysis of residual and 95\% confidence limit in Figure 17.

Given the limitations of the earlier rating equations described above, the HEC-RAS model results constitute the most reliable rating curve and equation for the entire Mukurumudzi River section at 3KD06, as it successfully takes into account different flow conditions and the transition between them.

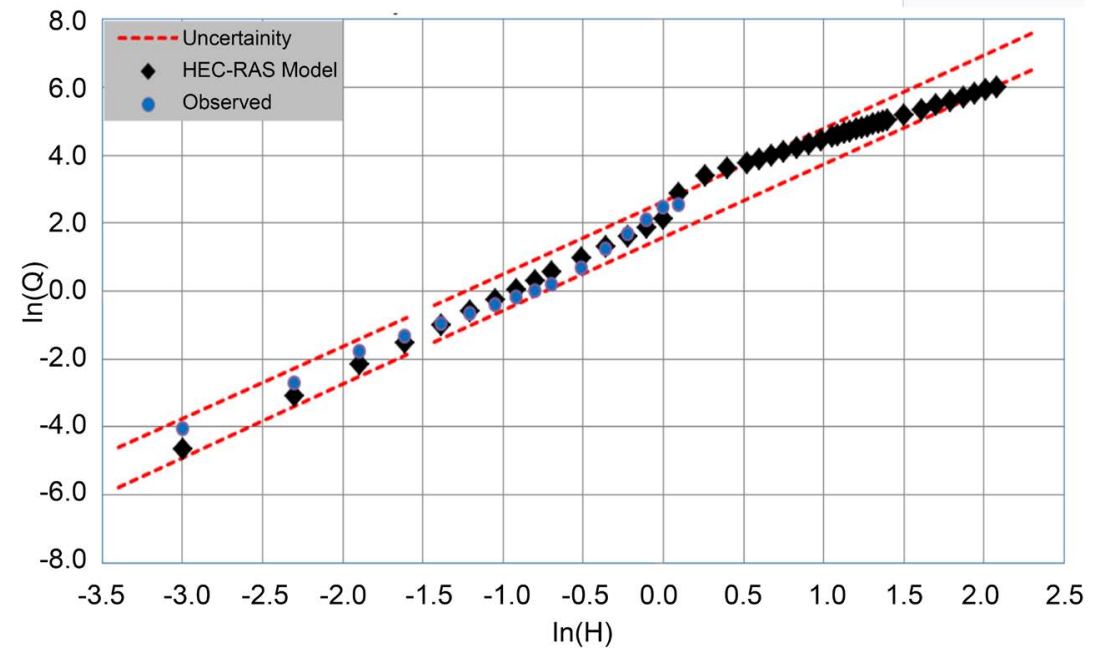

Figure 17. Uncertainty on the Mukurumudzi River at 3KD06 RGS.

\subsection{Mukurumudzi River at the KISCOL Weir}

The KISCOL diversion weir was a new monitoring site set up specifically to monitor residual flows downstream of the Upper and Lower Koromojo Dams and the two Mukurumudzi Dams (Base and KISCOL), community abstractions and other hydrological activities within the catchment. The diversion weir was one of the most complex structures studied within the HEC-RAS model environment. Figure 18 shows the topographical surface, with the diversion work as an inline structure within the river reach, as modelled in the HEC-RAS environment. The synthetic storm hydrograph (Figure $8(b)$ ) was routed through the 
weir section reach and calibrated with the measured H-Q by varying the Manning's $\mathrm{n}$ values for the channel, floodplain and bridge sections. The weir was modeled as an inline structure with a significant drop from the weir top to the downstream bed and gated weir at the bottom of the upstream end. The hydraulic behavior of the inline structure under unsteady flow condition was summarized in stage flow hydrographs for tail water and head water elevation at the entrance and exit of the structure. In this study, the discharge through the gated section increases with flow up to a maximum of $2.97 \mathrm{~m}^{3} / \mathrm{s}$, above which the head water (HT) ceases to control the flow (Figure 19).

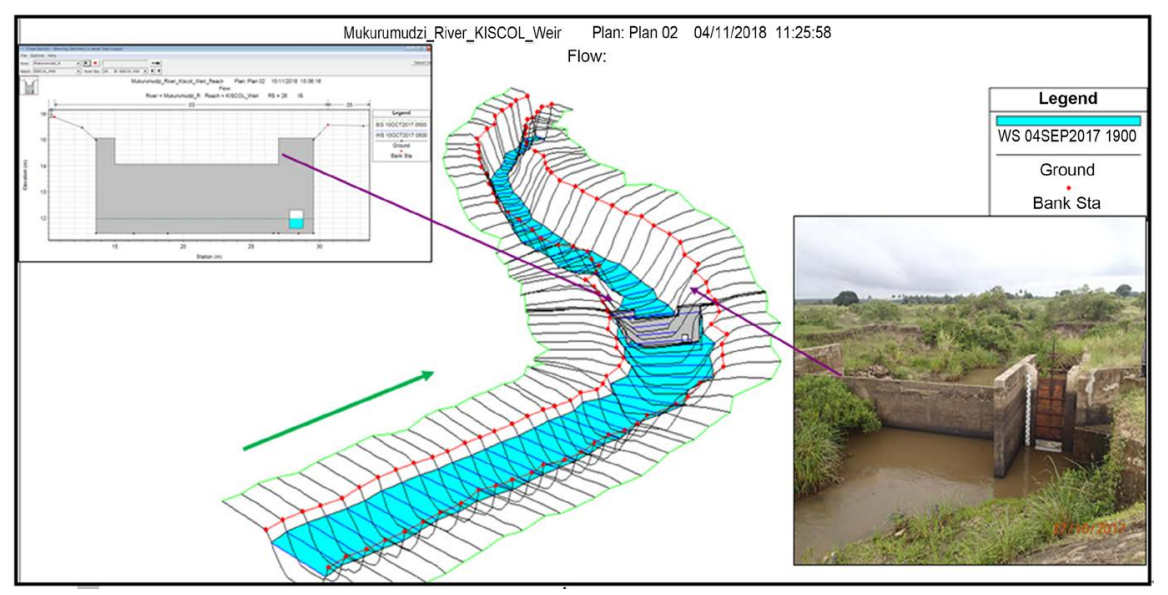

Figure 18. KISCOL weir topographical surface profile with diversion works as an inline structure.

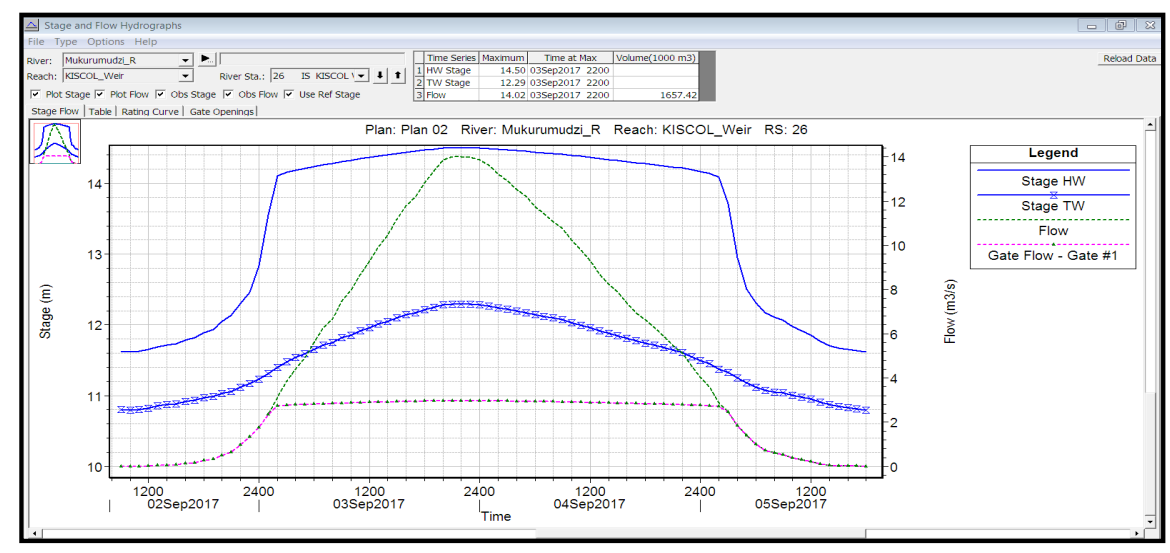

Figure 19. Stage flow hydrograph for Head Water (HT) and Tail Water (TW) at the KISCOL weir.

According to Doherty [30] and Chow [46], in stable channel sections Manning's roughness is predominantly influenced by vegetation, channel irregularity, channel alignment and obstructions. It appears that the accuracy of modeled water surface profiles become less sensitive to changes in Manning's $n$ than for channels influenced by mobile bed material. This phenomenon was experienced in modeling surface water profiles for the KISCOL weir section, where (during 
calibration), changes in Manning's $\mathrm{n}$ values for the channel as well as the flood plain had limited impacts on simulated water surface profiles (Figure 20 and Figure 21). When the flow increases and overflows the weir, direct measurement presented significant challenges. This necessitated moving the measuring point to a point some $650 \mathrm{~m}$ downstream from the weir to a controlled section, which increased the uncertainty of the measured discharge. Figure 20 shows the simulated flow of $5.4 \mathrm{~m}^{3} / \mathrm{s}(2.6 \mathrm{~m}$ stage $)$ against the observed of $6.6 \mathrm{~m}^{3} / \mathrm{s}$ at the same stage. It also proved difficult to simulate observed above the $2.7 \mathrm{~m}$ stage. Both the measured H-Q and the HEC-RAS model predictions for various Manning's values were fitted with a three-segment equation (Figure 21) and the Root Mean Squared Error $(\mathrm{RMSE}=2.66)$ used to compare the observed and simulated values. The HEC-RAS fitted rating curve adopted is shown in Table 5.

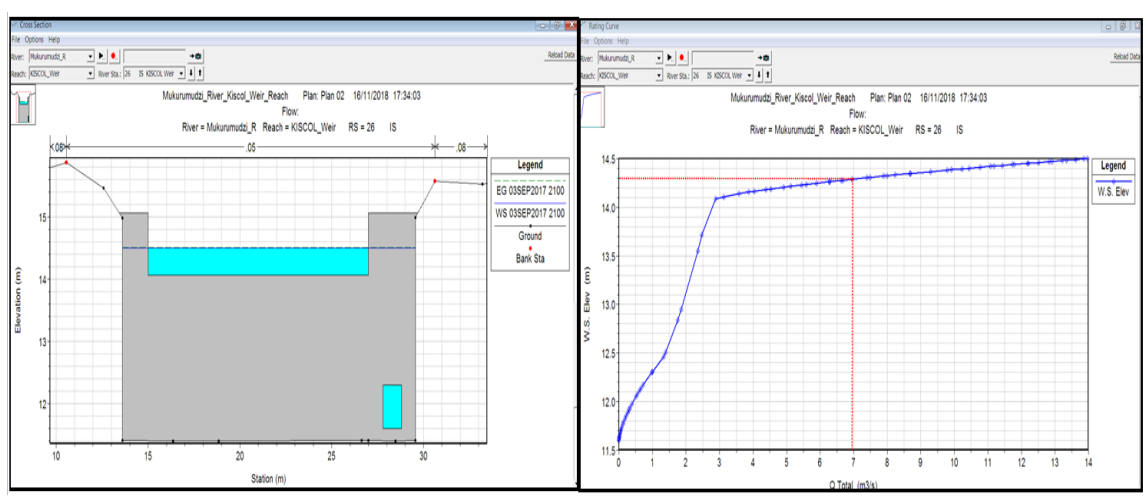

Figure 20. Simulated flow of $5.4 \mathrm{~m}^{3} / \mathrm{s}$ at $2.6 \mathrm{~m}$ stage (water surface elevation of $14.3 \mathrm{~m}$ ) at Kiscol weir RGS station.

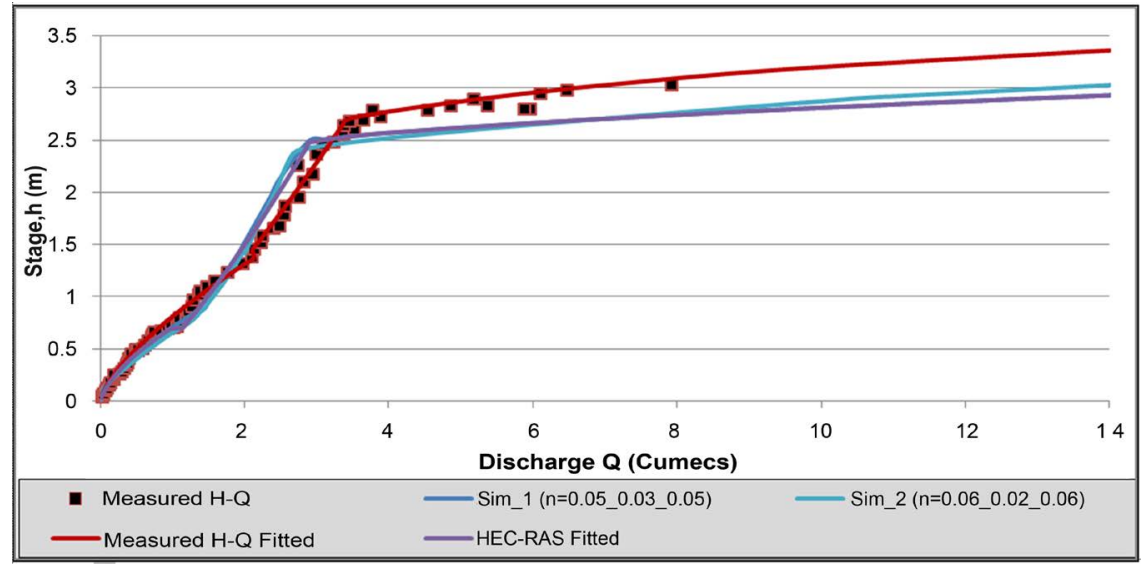

Figure 21. KISCOL weir measured H-Q and HEC-RAS, both simulated and fitted.

Table 5. KISCOL weir HEC-RAS fitted rating equation.

\begin{tabular}{ccccc}
\hline Segment & Depth Range, $\mathrm{h}$ & Equation & $\mathrm{R}^{2}$ & Function Type \\
\hline 1 & $\mathrm{~h}<0.7$ & $\mathrm{Q}=1.1801 \mathrm{~h}^{2}+0.602 \mathrm{~h}-0.0128$ & 0.999 & Polynomial \\
2 & $0.7<\mathrm{h}<2.5$ & $\mathrm{Q}=1.4846 \mathrm{~h}^{0.738}$ & 0.999 & Power Law \\
3 & $\mathrm{~h}>2.5$ & $\mathrm{Q}=0.0006 \mathrm{~h}^{9.4017}$ & 0.999 & Power Law \\
\hline
\end{tabular}




\subsection{Ramisi River Eshu Bridge Station}

The synthetic storm hydrograph (Figure 8(a)) was routed through the bridge section reach and calibrated with the measured H-Q by varying the Manning's $n$ values for the channel, floodplain and bridge sections (Figure 22).

Doherty [30] showed that wide alluvial river channels and uniform sections present challenges in determining the correct channel roughness. This is due to sands and gravels, which move constantly during high flow events [46]. The Ramisi River at the Eshu Bridge is one such section, with dynamic bed roughness characteristics which introduce complexity and uncertainty in the derivation of Manning's n, especially under low flow conditions (Figure 22).

Flow at heads less than $0.4 \mathrm{~m}$ spreads out across the wide river bed, making the measurement of discharge very difficult. The best fit was obtained for Manning's $\mathrm{n}$ values of 0.03 and 0.05 for the channel and floodplain respectively.

A flow of $300 \mathrm{~m}^{3} / \mathrm{s}$ is conveyed at a water depth of $4.55 \mathrm{~m}$ (21.35 m.asl) (Figure 23). The bridge cross section starts to become pressurized (culvert and overflowing weir) at much higher discharges of about $850 \mathrm{~m}^{3} / \mathrm{s}$. Fitting the curve provided a two-segment equation for the bridge section (Table 6). 5.3 Ramisi River Eshu Bridge Station.

The synthetic storm hydrograph (Figure 8(a)) was routed through the bridge section reach and calibrated with the measured H-Q by varying the Manning's $n$ values for the channel, floodplain and bridge sections (Figure 22).

Doherty [30] showed that wide alluvial river channels and uniform sections present challenges in determining the correct channel roughness. This is due to sands and gravels, which move constantly during high flow events [46]. The Ramisi River at the Eshu Bridge is one such section, with dynamic bed roughness characteristics which introduce complexity and uncertainty in the derivation of Manning's n, especially under low flow conditions (Figure 22).

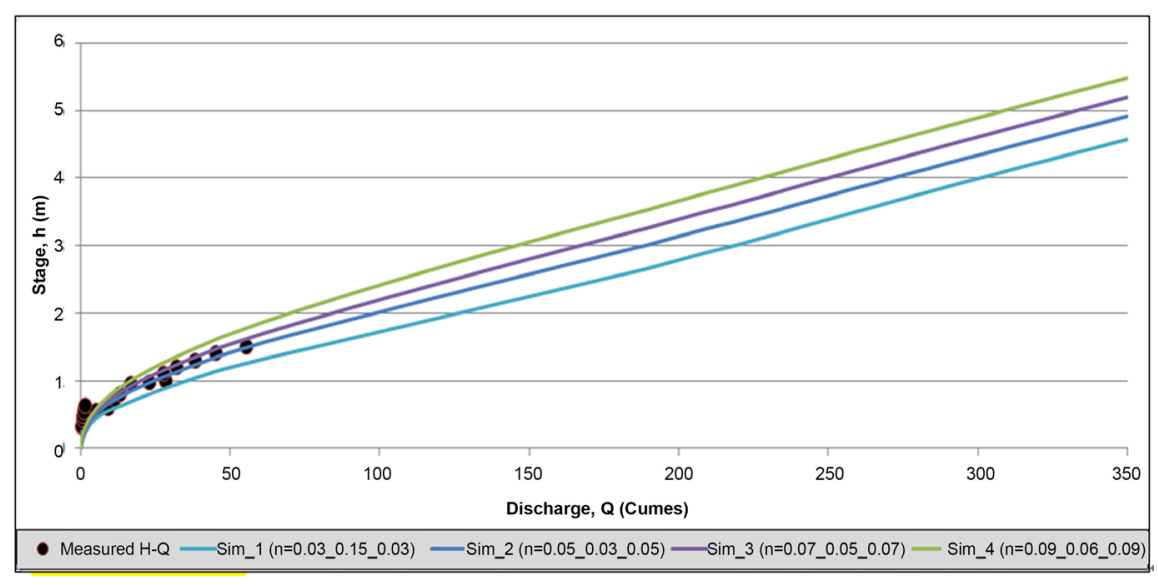

Figure 22. Ramisi River Eshu Bridge curves for various Manning's n values (channel and floodplain).

Flow at heads less than $0.4 \mathrm{~m}$ spreads out across the wide river bed, making the measurement of discharge very difficult. The best fit was obtained for Man- 
ning's $\mathrm{n}$ values of 0.03 and 0.05 for the channel and floodplain respectively.

A flow of $300 \mathrm{~m}^{3} / \mathrm{s}$ is conveyed at a water depth of $4.55 \mathrm{~m}(21.35 \mathrm{~m} \cdot \mathrm{asl})$ (Figure 23). The bridge cross section starts to become pressurized (culvert and overflowing weir) at much higher discharges of about $850 \mathrm{~m}^{3} / \mathrm{s}$. Fitting the curve provided a two-segment equation for the bridge section (Table 6).
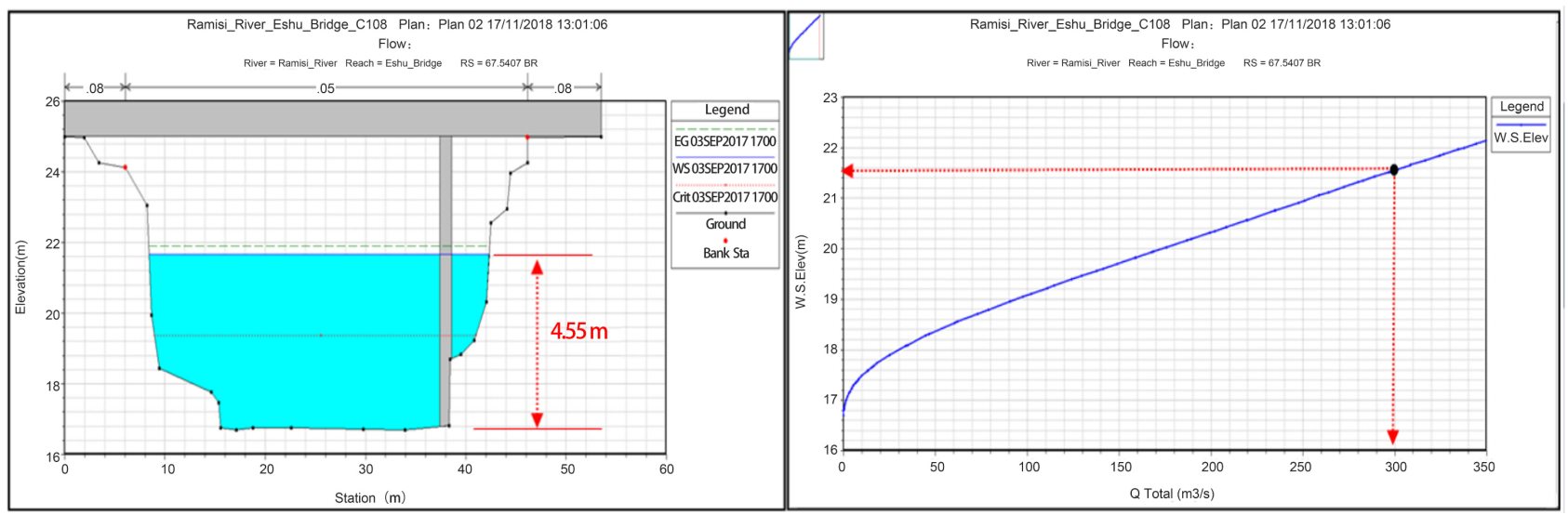

Figure 23. Ramisi River Eshu Bridge flow cross section and calibrated rating curve.

Table 6. Ramisi River at Eshu Bridge-two-segment equation.

\begin{tabular}{ccccc}
\hline Segment & Depth Range & Rating Curve Equation & $\mathbf{R}^{2}$ & Function Type \\
\hline 1 & $0.5<\mathrm{h} \leq 2.0$ & $\mathrm{Q}=31.026 \mathrm{~h}^{2}-8.965 \mathrm{~h}+1.2012$ & 0.9991 & Polynomial \\
2 & $2.0<\mathrm{h}<6$ & $\mathrm{Q}=49.2 \mathrm{~h}^{1.237}$ & 0.9941 & Power Law \\
\hline
\end{tabular}

\section{Conclusions and Recommendations}

Reviewing and establishing rating curves and equations for hydrometric stations using hydraulic modeling has immense potential for many benefits. These include timely establishment of stage-discharge relationship, developing a good understanding of the flow conditions within the section and reach and increased reliability of river flow data. It improves both the cost effectiveness and productivity of hydrographic work.

The impact of using an incorrect rating curve to estimate river discharge can be significant for water resources assessment and allocation planning. As shown, the Mukurumudzi River flow data are more reliable and accurate when the HEC-RAS rating curve is used, compared to the other three rating curves. For the other new stations (Ramisi River at the Eshu Bridge and the Mukurumudzi at the KISCOL weir), the HEC-RAS rating curve is the only reliable flow estimation method available.

Routine activities which include stage-discharge measurements, flood marking and vegetation density surveying are still critical in improving the confidence of the rating curves. On-site awareness needs to incorporate observations of open channel characteristics including; channel uniformity, consistency of slope, sediment deposition and bed stability within the monitoring river reach. Never- 
theless, immense opportunities still exist in the use of a HEC-RAS model to influence decision making on the use of hydraulic control structures for hydrometric monitoring stations.

The HEC-RAS approach has generally been used to develop rating curves for the total range of flows but has not been considered specifically as a tool for developing low-flow ratings as accurate discharge measurements are easier to undertake at low flows.

\section{Acknowledgements}

The authors gratefully acknowledge the support from the Gro for GooD research project team (University of Oxford, Rural Focus Ltd, University of Nairobi, Jomo Kenyatta University of Agriculture and Technology, Universitat Politècnica de Catalunya UPC), the Water Resources Authority (WRA), Base Titanium Ltd., Kwale, International Sugar Company (KISCOL) and Kenya Meteorological Department (KMD) for their support during the study. The UPGRO research project was financed by the UK's Department for International Development (DFID), and the Natural Environment Research Council (NERC).

\section{Conflicts of Interest}

The authors declare no conflicts of interest regarding the publication of this paper.

\section{References}

[1] Vogel, R.M. and Fennessey, N.M. (1995) Flow Duration Curves II: A Review of Applications in Water Resources Planning. Journal of the American Water Resources Association, 31, 1029-1039. https://doi.org/10.1111/j.1752-1688.1995.tb03419.x

[2] Clarke, R.T., Mendiondo, E.M. and Brusa, L.C. (2000) Uncertainties in Mean Discharges from Two Large South American Rivers Due to Rating Curve Variability. Hydrological Sciences Journal, 45, 221-236. https://doi.org/10.1080/02626660009492321

[3] Lam, N. (2017) Modeling Rating Curves from Close-Range Remote Sensing Data: Application of Laser and Acoustic Ranging Instruments for Capturing Stream Channel Topography. Doctoral Dissertation, US-AB.

[4] Le Coz, J., Renard, B., Bonnifait, L., Branger, F. and Le Boursicaud, R. (2014) Combining Hydraulic Knowledge and Uncertain Gaugings in the Estimation of Hydrometric Rating Curves: A Bayesian Approach. Journal of Hydrology, 509, 573-587. https://doi.org/10.1016/j.jhydrol.2013.11.016

[5] World Meteorological Organisation (1994) Guide to Hydrological Practice. WMO Pubblicità, No. 168.

[6] ISO (International Standards Organization) (1998) ISO 1100/2 1998, Stage-Discharge Relation. International Standards Organization, Geneva.

[7] Dottori, F., Martina, M.L.V. and Todini, E. (2009) A Dynamic Rating Curve Approach to Indirect Discharge Measurement. Hydrology and Earth System Sciences, 13, 847-863. https://doi.org/10.5194/hess-13-847-2009

[8] Crawford, C.G. (1991) Estimation of Suspended-Sediment Rating Curves and Mean 
Suspended-Sediment Loads. Journal of Hydrology, 129, 331-348.

https://doi.org/10.1016/0022-1694(91)90057-O

[9] Milliman, J.D. and Kao, S.J. (2005) Hyperpycnal Discharge of Fluvial Sediment to the Ocean: Impact of Super-Typhoon Herb (1996) on Taiwanese Rivers. The Journal of Geology, 113, 503-516. https://doi.org/10.1086/431906

[10] Herschy, R.W. (2014) Streamflow Measurement. CRC Press, Boca Raton. https://doi.org/10.1201/9781482271485

[11] Fread, D.L. (1975) Computation of Stage-Discharge Relationship Affected by Unsteady Flow. Journal of the American Water Resources Association, 11, 429-442. https://doi.org/10.1111/j.1752-1688.1975.tb00674.x

[12] Ward, B. and Thomas, L. (2014) Does Your Rating Curve Hold Water? The Consequences of Rating Curve Errors. ANCOLD Conference. Canberra, Australia, 21-22 October 2014.

[13] Ackers, P. (1993) Stage-Discharge Functions for Two-Stage Channels: The Impact of New Research. Water and Environment Journal, 7, 2-59. https://doi.org/10.1111/j.1747-6593.1993.tb00810.x

[14] Léonard, J., Mietton, M., Najib, H. and Gourbesville, P. (2000) Rating Curve Modelling with Manning's Equation to Manage Instability and Improve Extrapolation. Hydrological Sciences Journal, 45, 739-750. https://doi.org/10.1080/02626660009492374

[15] Timbadiya, P.V., Patel, P.L. and Porey, P.D. (2011) Calibration of HEC-RAS Model on Prediction of Flood for Lower Tapi River, India. Journal of Water Resource and Protection, 3, 805. https://doi.org/10.4236/jwarp.2011.311090

[16] Muste, M. and Lee, K. (2013) Quantification of Hysteretic Behavior in Stream Flow Rating Curves. Proceedings of the 35 th IAHR World Congress, Chengdu, China, 8-13 September 2013.

[17] Reistad, S.K., Petersen-Øverleir, A. and Bogetveit, L.J. (2007) Setting Up Rating Curves Using HEC-RAS. Journal of Korea Water Resources Association, 3, 20-30.

[18] Kuczera, G. (1996) Correlated Rating Curve Error in Flood Frequency Inference. Water Resources Research, 32, 2119-2127. https://doi.org/10.1029/96WR00804

[19] Di Baldassarre, G. and Claps, P. (2011) A Hydraulic Study on the Applicability of Flood Rating Curves. Hydrology Research, 42, 10-19. https://doi.org/10.2166/nh.2010.098

[20] Bozzi, S., Passoni, G., Bernardara, P., Goutal, N. and Arnaud, A. (2015) Roughness and Discharge Uncertainty in 1D Water Level Calculations. Environmental Modeling and Assessment, 20, 343-353. https://doi.org/10.1007/s10666-014-9430-6

[21] Di Baldassarre, G. and Montanari, A. (2009) Uncertainty in River Discharge Observations: A Quantitative Analysis. Hydrology and Earth System Sciences, 13, 913-921. https://doi.org/10.5194/hess-13-913-2009

[22] Vanmaercke, M., Zenebe, A., Poesen, J., Nyssen, J., Verstraeten, G. and Deckers, J. (2010) Sediment Dynamics and the Role of Flash Floods in Sediment Export from Medium-Sized Catchments: A Case Study from the Semi-Arid Tropical Highlands in Northern Ethiopia. Journal of Soils and Sediments, 10, 611-627. https://doi.org/10.1007/s11368-010-0203-9

[23] Dymond, J.R. and Christian, R. (1982) Accuracy of Discharge Determined from a Rating Curve. Hydrological Sciences Journal, 27, 493-504. https://doi.org/10.1080/02626668209491128

[24] Pappenberger, F., Beven, K., Horritt, M. and Blazkova, S. (2005) Uncertainty in the 
Calibration of Effective Roughness Parameters in HEC-RAS Using Inundation and Downstream Level Observations. Journal of Hydrology, 302, 46-69. https://doi.org/10.1016/j.jhydrol.2004.06.036

[25] Morvan, H., Knight, D., Wright, N., Tang, X. and Crossley, A. (2008) The Concept of Roughness in Fluvial Hydraulics and Its Formulation in 1D, 2D and 3D Numerical Simulation Models. Journal of Hydraulic Research, 46, 191-208. https://doi.org/10.1080/00221686.2008.9521855

[26] Di Baldassarre, G., Castellarin, A. and Brath, A. (2009) Analysis of the Effects of Levee Heightening on Flood Propagation: Example of the River Po, Italy. Hydrological Sciences Journal, 54, 1007-1017. https://doi.org/10.1623/hysj.54.6.1007

[27] Castellarin, A., Di Baldassarre, G., Bates, P.D. and Brath, A. (2009) Optimal CrossSectional Spacing in Preissmann Scheme 1D Hydrodynamic Models. Journal of Hydraulic Engineering, 135, 96-105. https://doi.org/10.1061/(ASCE)0733-9429(2009)135:2(96)

[28] Sönmez, O. and Doğan, E. (2016) Determination of Flood Inundation Area in Cedar River Using Calibrated and Validated $1 \mathrm{D}$ and 1D/2D Model. SAÜ Fen Bil Der, 20, 337-347.

[29] Mansanarez, V., Le Coz, J., Renard, B., Lang, M., Pierrefeu, G. and Vauchel, P. (2016) Bayesian Analysis of Stage-Fall-Discharge Rating Curves and Their Uncertainties. Water Resources Research, 52, 7424-7443. https://doi.org/10.1002/2016WR018916

[30] Doherty, R. (2010) Calibration of HEC-RAS Models for Rating Curve Development in Semi-Arid Regions of Western Australia. American Heart Association (AHA) 2010 Scientific Sessions, 13-17 November 2010, Chicago, Illinois.

[31] Lee, K.T., Ho, Y.H. and Chyan, Y.J. (2006) Bridge Blockage and Overbank Flow Simulations Using HEC-RAS in the Keelung River during the 2001 Nari Typhoon. Journal of Hydraulic Engineering, 132, 319-323. https://doi.org/10.1061/(ASCE)0733-9429(2006)132:3(319)

[32] Shao, Q., Dutta, D., Karim, F. and Petheram, C. (2018) A Method for Extending Stage-Discharge Relationships Using a Hydrodynamic Model and Quantifying the Associated Uncertainty. Journal of Hydrology, 556, 154-172.

https://doi.org/10.1016/j.jhydrol.2017.11.012

[33] Grout \& Shotcrete (2011) Hydrological Contract KISCO/AG/IR/2011. Water Resources Assessment and Analysis for Mkurumudzi River and Adjacent Catchments in Kwale International Sugar Company Ltd. (KISCOL). Final Report.

[34] Katuva, J.M., Omuto, C.T. and Obiero, J.P. (2014) Water Allocation Assessment and Hydrological Simulation on Mukurumudzi River Basin in Kenya. In: Marigi, S.N., Ed., Hydrology and Best Practices for Managing Water Resources in Arid and Semi-Arid Lands, IGI Global, Hershey, 51-69.

[35] Ouédraogo, W., Raude, J. and Gathenya, J. (2018) Continuous Modeling of the Mkurumudzi River Catchment in Kenya Using the HEC-HMS Conceptual Model: Calibration, Validation, Model Performance Evaluation and Sensitivity Analysis. Hydrology, 5, 44. https://doi.org/10.3390/hydrology5030044

[36] Streamtec Pty Ltd. (2011) Environmental Water Requirements for the Mukurumudzi River, Kwale, Kenya (Streamtec Report 8/2011). Base Titanium.

[37] Rural Focus Ltd. (2014) Rating Curve Study for RGS 3KD06 on Mukurumudzi River, Kwale, Kenya (Rural Focus Report 2014).

[38] Chalala, A. and Chimbevo, L.M. (2015) Sea Water Intrusion and Surface Water Salinity and Its Influence on Irrigation Water Quality in Ramisi Area, Kenya. Journal 
of Agriculture and Ecology Research International, 12, 1-13.

[39] Tole, M.P. (1990) Present Day Ore Deposition in the Geothermal Systems of Kenya-I. The Mwananyamala Hot Springs, Northeast of Jombo Hill, Coast Province. Geothermics, 19, 233-239. https://doi.org/10.1016/0375-6505(90)90019-8

[40] Hydrologic Engineering Centre (March 2008) HEC-RAS, River Analysis System Hydraulic Reference Manual.

[41] Hydrologic Engineering Center (2016) HEC-HEC-RAS 5.0 Hydraulic Reference Manual.

[42] Xiong, Y. (2011) A Dam Break Analysis Using HEC-RAS. Journal of Water Resource and Protection, 3, 370-379. https://doi.org/10.4236/jwarp.2011.36047

[43] US Army Corps of Engineers, Hydrologic Engineering Center, HEC-RAS, User's Manual, Version 5.04, 2017.

[44] Horritt, M.S. and Bates, P.D. (2002) Evaluation of 1D and 2D Numerical Models for Predicting River Flood Inundation. Journal of Hydrology, 268, 87-99. https://doi.org/10.1016/S0022-1694(02)00121-X

[45] Takasu, T. and Yasuda, A. (2008) November. Evaluation of RTK-GPS Performance with Low-Cost Single-Frequency GPS Receivers. Proceedings of International Symposium on GPS/ GNSS, Odaiba, Tokyo, 11-14 November 2008, 852-861.

[46] Chow, V.T. (1959) Open-Channel Hydraulics. McGraw-Hill, New York.

[47] Domeneghetti, A., Castellarin, A. and Brath, A. (2012) Assessing Rating-Curve Uncertainty and Its Effects on Hydraulic Model Calibration. Hydrology and Earth System Sciences, 16, 1191-1202. https://doi.org/10.5194/hess-16-1191-2012

[48] Ogunlela, A.O., Adewale, P.O. and Adamowski, J.F. (2012) Developing Design Storm Hydrographs for Small Tropical Catchments with Limited Data. Ethiopian Journal of Environmental Studies and Management, 5, 356-365. https://doi.org/10.4314/ejesm.v5i4.4

[49] Gräler, B., Van Den Berg, M., Vandenberghe, S., Petroselli, A., Grimaldi, S., De Baets, B. and Verhoest, N. (2013) Multivariate Return Periods in Hydrology: A Critical and Practical Review Focusing on Synthetic Design Hydrograph Estimation. Hydrology and Earth System Sciences, 17, 1281-1296.

https://doi.org/10.5194/hess-17-1281-2013 